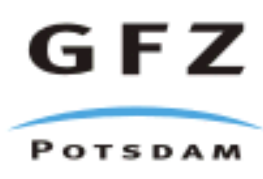

Originally published as:

Haberland, C., Rietbrock, A., Lange, D., Bataille, K., Hofmann, S. (2006): Interaction between forearc and oceanic plate at the south-central Chilean margin as seen in local seismic data. - Geophysical Research Letters, 33, L23302

DOI: 10.1029/2006GL028189. 


\section{Interaction between forearc and oceanic plate at the South-Central Chilean margin as seen in local seismic data}

Ch. Haberland, ${ }^{1}$ A. Rietbrock, ${ }^{2}$ D. Lange, ${ }^{1}$ K. Bataille, ${ }^{3}$ and S. Hofmann ${ }^{4}$

Christian Haberland, Institute of Geoscience, University of Potsdam, Karl-Liebknecht- Str. 24, 14476 Golm, Germany (haber@geo.uni-potsdam.de)

Andreas Rietbrock, Department of Earth and Ocean Sciences, University of Liverpool, UK, (A.Rietbrock@liverpool.ac.uk)

Dietrich Lange, Institute of Geoscience, University of Potsdam, Germany, (dlange@geo.unipotsdam.de)

Klaus Bataille, Dept. Ciencias De La Tierra, Universidad de Concepción, Chile, (bataille@udec.cl)

Sonja Hofmann, Institute of Geophysics, University of Hamburg, Germany, (Sonja.Hofmann@dkrz.de)

${ }^{1}$ Institute of Geosciences, University of

D R A F T

October 23, 2006, 3:39pm

D R A F T 
${ }_{4} \quad$ We installed a dense, amphibious, temporary seismological network to study

5 the seismicity and structure of the seismogenic zone in southern Chile be-

6 tween $37^{\circ}$ and $39^{\circ} \mathrm{S}$, the nucleation area of the great 1960 Chile earthquake.

7213 local earthquakes with 14.754 onset times were used for a simultaneous

${ }_{8}$ inversion for the 1-D velocity model and precise earthquake locations. Re-

9 located artificial shots suggest an accuracy of the earthquake hypocenter of

${ }_{10}$ about $1 \mathrm{~km}$ (horizontally) and $500 \mathrm{~m}$ (vertically). Crustal events along trench-

${ }_{11}$ parallel and transverse, deep-reaching faults reflect the interseismic trans-

${ }_{12}$ pressional deformation of the forearc crust due to the subduction of the Nazca

${ }_{13}$ plate. The transverse faults seems to accomplish differential lateral stresses

${ }_{14}$ between subduction zone segments. Many events situated in an internally

15 structured, planar seismicity patch at 20 to $40 \mathrm{~km}$ depth near the coast in-

${ }_{16}$ dicate a stress concentration at the plate's interface at $38^{\circ} \mathrm{S}$ which might

${ }_{17}$ in part be induced by the fragmented forearc structure.

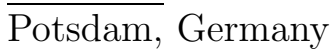

${ }^{2}$ Department of Earth and Ocean

Sciences, The University of Liverpool, UK

${ }^{3}$ Dept. Ciencias De La Tierra,

Universidad de Concepción, Chile

${ }^{4}$ Institute of Geophysics, University of

Hamburg, Germany
} 


\section{Introduction}

${ }_{18}$ The largest earthquakes are being generated at convergent plate boundaries, where

oceanic plates subduct beneath other tectonic plates [Pacheco et al., 1993]. More precisely,

these earthquakes are being generated at the relatively shallow portions of the interface between both plates, the coupling zone or seismogenic zone, where the (moving) plates are locked for considerable periods of time thus accumulating elastic stresses [e.g. Hyndman et al., 1997]. Large interplate earthquakes result from successive ruptures of subsequent segments of these coupling zones following stick-slip frictional behavior [Scholz, 2002].

The coupling, which is a measure of the seismogenic mechanical interaction between the plates and decisive for the occurrence of large earthquakes, seems to be highly nonuniform (both along strike and in comparison with other subduction zones). Even during large earthquakes, regions along these plate boundaries with large coseismic slip and moment release, known as asperities, alternate with sectors characterized by relatively small slip [Lay and Kanamori, 1981].

However, there is much discussion about the physical properties of those observed asperities, which ultimately are the controlling factors of plate coupling and the occurrence of megathrust earthquakes. Many studies focused on the lower plate and discussed parameters such as the plate roughness, the sea floor age, the trench sediment fill, the convergence velocity/obliquity, the temperature field [Oleskevich et al., 1999], the history [Kanamori, 1977], and other parameters [e.g., Kanamori, 1986, and references within]. Less attention had been paid to potential controlling parameters related to the upper plate [McCaffrey, 1993; Collot et al., 2004; Song and Simons, 2003; Fuller et al., 2006]. 
${ }_{39}$ Here, we use high-resolution local observations of the "minor" subduction zone seis-

40 micity occurring during the interseismic cycle to characterize the coupling zone and the

${ }_{41}$ forearc of the southern Chilean convergent margin $\left(37^{\circ}-39^{\circ} \mathrm{S}\right)$ and the interplay between

${ }_{42}$ the upper and lower plate.

${ }_{43}$ At this location at May 22, 1960 the worldwide largest instrumentally observed earth${ }_{44}$ quake $(\mathrm{M}=9.5)$ nucleated and ruptured the almost $1000 \mathrm{~km}$ long segment from the Arauco 45 peninsula (AP) southward down to the triple junction [Plafker and Savage, 1970; Barrien-

\section{Experiment, Data}

${ }_{55}$ Between Nov. 2004 and June 2005 a dense, amphibious, seismological network was ${ }_{56}$ installed in southern Chile, covering the entire forearc between $37^{\circ}$ and $39^{\circ} \mathrm{S}[$ Rietbrock 
${ }_{60}$ sample rate. All recorders were equipped with Mark L4-3D short period sensors, and

${ }_{61}$ they were running continuously. Between February and October 2005 ten ocean bottom

${ }_{62}$ seismometers/hydrophones (OBS/OBH, six of them producing data) complemented the

${ }_{63}$ network off-shore (Figure 1). Finally, 20 land stations and ten OBS/OBH stations re-

${ }_{64}$ mained in the region until October 2005. OBS/OBH data could be used for the first time

${ }_{65}$ for seismological studies in this region. Average station spacings were very small in the

${ }_{66}$ center (around $7 \mathrm{~km}$ ) and larger in the outskirts of the region of interest $(40 \mathrm{~km})$. On

${ }_{67}$ average the network observed 2 to 3 local events per day.

\section{Analysis and Inversion}

${ }_{68}$ Events were detected by applying an automatic STA/LTA trigger together with a down-

${ }_{69}$ stream temporal coincidence check. Arrival times of the compressional (P) and shear

70 (S) waves were manually picked with the GIANT/PITSA software code [Rietbrock and

${ }_{71}$ Scherbaum, 1998]. In total we located 544 local events with magnitudes between 1 and

${ }_{72} 5.2 M_{L}$. A high quality subset based on 213 events with $8.988 \mathrm{P}$ and $5.766 \mathrm{~S}$ picks was

73 used for a simultaneous inversion for accurate hypocenters, 1-D velocity model and station

${ }_{74}$ corrections [Kissling et al., 1994]. We first inverted for the $v_{p}$ model assuming a constant

${ }_{75}$ average $v_{p} / v_{s}$ ratio of 1.77 (based on Wadati diagram analysis) and using a wide range

${ }_{76}$ of starting models. In a second step we used the final $v_{p}$ model (from the first step) and

${ }_{77}$ varying constant $v_{p} / v_{s}$ values as starting models in subsequent inversions [Husen et al.,

78 1999]. Inversions based solely on $\mathrm{P}$ picks resulted in almost identical hypocenter positions

${ }_{79}$ in the central parts of the network (i.e. shallower than $50 \mathrm{~km}$ depth). The finely-layered

so minimum 1-D model starts with rather high crustal $v_{p}$ of $6 \mathrm{~km} / \mathrm{s}$ at the surface, increasing

D R A F T October 23, 2006, 3:39pm D R A F T 
${ }_{81}$ gently to about $7 \mathrm{~km} / \mathrm{s}$ at a depth of $30 \mathrm{~km}$ (Figure 2). Due to the dense network and

${ }_{82}$ also uppercrustal earthquakes even the uppermost layers are well constrained and model

\section{Accuracy of earthquake locations}

${ }_{88}$ In order to estimate the accuracy of the hypocenter locations we located chemical ex-

s9 plosions of an accompanying active source seismic experiment [Krawczyk et al., 2005] in

90 the same way as we located the earthquakes. These shots were not part of the data used

${ }_{91}$ for the inversion described above. The comparison between actual and inverted loca-

${ }_{92}$ tions suggests that the uncertainty in horizontal and vertical direction of earthquakes

93 beneath central parts of the network is better than $1 \mathrm{~km}$ and $500 \mathrm{~m}$, respectively (Figure

94 3). Uncertainties in absolute hypocenter position for deeper earthquakes are considered

${ }_{95}$ to be smaller than the estimates deduced from the shots since the travel times of the

${ }_{96}$ corresponding raypaths are less affected by the expected heterogenous velocity structure ${ }_{97}$ close to the surface (not accounted for in the 1-D velocity model) [Kissling, 1988].

\section{Results in Discussion}

${ }_{98}$ Seismicity is found from the surface down to $115 \mathrm{~km}$ depth. The earthquakes can now 99 be clearly associated with locations within the oceanic plate, the continental plate, and 100

D R A F T

October 23, 2006, 3:39pm
D R A F T 


\subsection{Intraplate seismicity - upper and lower plate}

A surprisingly large number of earthquakes is found in the continental crust and can in most cases be associated with mapped faults (B, C, and D in Figure 4).

In the coastal area a crustal $M_{L} 5.2$ event occured at February 4, 2005 $\left(73.47^{\circ} \mathrm{W} / 37.92^{\circ} \mathrm{S} / 12.2 \mathrm{~km}\right.$ depth) followed by a large number of aftershocks (B in Figure 4). These and several other smaller events are related to NNW-SSE striking reverse faults close to the coast South of the AP (although the large event has mainly strike-slip character). These, deep-reaching faults, which were also imaged by industry seismic reflection profiles, accommodate the margin-normal forearc shortening, which is in part responsible for the local uplift of the AP [e.g., Melnick et al., 2006].

A number of strike-slip earthquakes is delineated along NW-SE striking faults such as the Lanalhue fault (LFZ) and a northern fault strand (C in Figure 4). The seismic activity along these faults is situated between 10 and $30 \mathrm{~km}$ depth indicating that these faults are deep reaching and cut through almost the whole forearc crust. According to the mapped fault trace at the surface [Melnick and Echtler, 2006] and the hypocenters, the LFZ appears to be near-vertical. This seismic activity thus reflects the recent, brittle deformation of the forearc along crustal-scale transverse faults. It can be related to the clockwise forearc block rotation due to the obliqueness of the subduction of the Nazca plate proposed e.g. by Echtler et al. [2003]. Additionally, the activity along these transverse faults indicates the decoupling of adjacent margin segments (i.e. North and South of the LFZ) which could accomplish the transfer of differential lateral stresses between segments at different stages of the seismic cycle (i.e., segments associated with the 1835 and 1960 

$1394)$.

\subsection{Interplate seismicity} 4).

earthquakes). A pronounced post-seismic, large-scale crustal deformation in the area of (and in response to) the great 1960 earthquake differing from the deformation in the northerly adjacent segment, which is currently in the interseismic cycle, was observed by GPS studies [Khazaradze et al., 2002]. It had been previously proposed that such transverse faults could also control the extent of seismogenic ruptures [Collot et al., 2004]. Crustal seismicity at depth smaller than $30 \mathrm{~km}$ at about $71.2^{\circ} \mathrm{W}$ (although situated at the edge of the network) is evidence for recent activity of the almost arc-parallel Liquiñe-Ofqui fault zone (LOFZ, in Figure 4). This large right-lateral shear zone cuts the Patagonian batholith and controls the architecture of the modern volcanic arc of southern Chile thus accomplishing the lateral northward movement of a forearc sliver due to oblique subduction [Cembrano et al., 2000].

At depths between 50 and $115 \mathrm{~km}$ intermediate depth seismicity (E in Figure 4) is found in a plane dipping easterly [see also Bohm et al., 2002]. The dip is approx. 25 between 72 and $73^{\circ} \mathrm{W}$. Intense intermediate seismicity was found to be dominating in the subduction zone section just north of the AP [Campos et al., 2002]. These events are generally attributed to phase transformations and dehydration embrittlement within the subducting plate. Few events are found in the subducting slab off the coast (F in Figure

Beneath the coast we find a persistent patch of increased seismicity at a depth between 20 and $40 \mathrm{~km}$ (A in Figure 4). In map view, the events are not uniformly distributed within this patch and reflect an internal structure with often linearly aligned earthquakes. 
${ }_{143}$ The collocation in a very narrow $(\sigma=1.6 \mathrm{~km})$, almost flat plane (dip $9^{\circ}-11^{\circ} \mathrm{E}, 73.75^{\circ}$ $\left.{ }_{144}-73^{\circ} \mathrm{W}, 38.25^{\circ}-37.5^{\circ} \mathrm{S}\right)$ suggests that these events occur at the interface between the 145 subducting and the upper plate. The downdip limit of this patch is around $40 \mathrm{~km}$ depth ${ }_{146}$ which is at the lower bound of the estimates for the downdip limit of the seismogenic 147 zone based on the distribution of hypocenters of large earthquakes $(40-53 \mathrm{~km})$ in the ${ }_{148}$ region [Tichelaar and Ruff, 1991]. W of $74^{\circ} \mathrm{W}$ this seismicity diminishes. The width of 


\section{Conclusions}


M. Strecker, and two anonymous reviewers provided helpful comments. All figures were made with the GMT program [Wessel and Smith, 1998].

\section{References}

Barrientos, S., and S. Ward, The 1960 Chile earthquake: inversion for slip distribution from surface deformation, Geophys. J. Int., 103, 589-598, 1990.

Bilek, S. L., and T. Lay, Tsunami earthquakes possibly widespread manifestations of frictional conditional stability, Geophys. Res. Lett., 29(14), doi:10.1029/2002GL015215, 2002.

Bohm, M., S. Lüth, H. Echtler, G. Asch, K. B. K., C. Bruhn, A. Rietbrock, and P. Wigger, The southern Andes between $36^{\circ}$ and $40^{\circ}$ s latitude: Seismicity and average seismic velocities, Tectonophysics, 356(4), 275-289, 2002.

Campos, J., et al., A seismological study of the 1835 seismic gap in south-central Chile, Phys. Earth Planet. Inter., 132, 177-195, 2002.

Cembrano, J., E. Schermer, A. Lavenu, and A. Sanhueza, Contrasting nature of deformation along an intra-arc shear zone, the Liquine-Ofqui fault zone, southern Chilean Andes, Tectonophysics, 319(2), 129-149, 2000.

Cifuentes, I. L., The 1960 Chilean Earthquakes, J. Geophys. Res., 94(B1), 665-680, 1989.

Collot, J.-Y., B. Marcaillou, F. Sage, F. Michaud, W. Agudelo, P. Charvis, D. Graindorge, M.-A. Gutscher, and G. Spence, Are rupture zone limits of great subduction earthquakes controlled by upepr plate structures? Evidence from multichannel seismic reflection data across the northern Ecuador-southwest Colombia margin, J. Geophys. Res., 109, doi:10.1029/2004JB003060, 2004. 
Echtler, H., J. Glodny, K. Gräfe, M. Rosenau, D. Melnick, W. Seifert, and T. Vietor, Active tectonics controlled by inherited structures in the long-term stationary and nonplateau south-central andes, EGS - AGU - EUG Joint Assembly, Nice, France, pp. EAE03-A-10,902, 2003.

Engdahl, E., R. Van Der Hilst, and R. Buland, Global teleseismic earthquake relocation with improved travel time and procedures for depth determination, Bull. Seismol. Soc. Am., 88(3), 722-743, 1998.

Engdahl, R., and A. Villaseñor, Global seismicity: 1900 - 1999, in International Handbook of Earthquake and Engineering Seismology, edited by W. H. K. Lee, H. Kanamori, and P. Jennings, pp. 665-690, IASPEI, part A, Chapter 41, 2002.

Fuller, C. W., S. D. Willett, and M. T. Brandon, Formation of forearc basins and their influence on subduction zone earthquakes, Geology, 34(2), 65-68, doi: 10.1130/G21828.1;0, 2006.

Hackney, R., et al., The segmented overriding plate and coupling at the south-central Chilean margin (36-42 $\mathrm{S})$, in The Andes - Active Subduction Orogeny, Frontiers in Earth Sciences, vol. 1, edited by O. Oncken et al., pp. 355-374, Springer, Berlin, Heidelberg, 2006.

Husen, S., E. Kissling, E. Flüh, and G. Asch, Accurate hypocentre determination in the seismogenic zone of the subducting Nazca Plate in northern Chile using a combined on-/offshore network, Geophys. J. Int., 138(3), 687-701, 1999.

Hyndman, R., M. Yamano, and D. Oleskevich, The seismogenic zone of subduction thrust faults, The Island Arc, 6, 244-260, 1997. 
Kanamori, H., Energy-release in great earthquakes, J. Geophys. Res., 82(20), 2981-2987, 1977.

Kanamori, H., Rupture process of subduction-zone earthquakes, Annu. Rev. Earth Planet. Sci., 14, 293-322, 1986.

Khazaradze, G., K. Wang, J. Klotz, Y. Hu, and J. He, Prolonged post-seismic deformation of the 1960 great Chile earthquake and implications for mantle rheology, Geophys. Res. Lett., 29(2), 2050, doi:10.1029/2002GL015986, 2002.

Kissling, E., Geotomography with local earthquake data, Rev. of Geophys., 26, 659-698, 1988.

Kissling, E., W. Ellsworth, D. Eberhart-Phillips, and U. Kradolfer, Initial reference models in local earthquake tomography, J. Geophys. Res., 99, B10, 1994.

Krawczyk, C., et al., Imaging the seismogenic coupling zone in Chile: The 3-component reflection seismic survey of project TIPTEQ, EOS Trans. AGU, 2005.

Lay, T., and H. Kanamori, An asperity model of large earthquake sequences, in Earthquake prediction: an international review, vol. 4, edited by D. Simpson and P. G. Richards, pp. 579-592, AGU, 1981.

McCaffrey, R., On the role of the upper plate in great subduction zone earthquakes, J. Geophys. Res., 81 (B7), 11,953-11,966, 1993.

Melnick, D., and H. P. Echtler, Morphotectonic and geologic digital map compilations of the south-central Andes $\left(36^{\circ}-42^{\circ} \mathrm{S}\right)$, in The Andes - Active Subduction Orogeny, Frontiers in Earth Sciences, vol. 1, edited by O. Oncken et al., pp. 565-568, Springer, Berlin, Heidelberg, New York, 2006. 
Melnick, D., B. Bookhagen, H. Echtler, and M. Strecker, Coastal deformation and great subduction earthquakes, Isla Santa María, Chile (37 S), Geol. Soc. Am. Bull., 118(11), 1463-1480, doi:10.1130/B25865.1, 2006.

Oleskevich, D., R. Hyndman, and K. Wang, The updip and downdip limits to great subduction earthquakes: Thermal and structural models of Cascadia, south Alaska, SW Japan, and Chile, J. Geophys. Res., 104(B7), 14,965-14,991, 1999.

Pacheco, J., L. Sykes, and C. Scholz, Nature of seismic coupling along simple plate boundaries of the subduction type, J. Geophys. Res., 98(B8), 14,133-14,159, 1993.

Plafker, G., and J. C. Savage, Mechanism of the Chilean earthquake of May 21 and 22, 1960, Geol. Soc. Am. Bull., 81, 1001-1030, 1970.

Rietbrock, A., and F. Scherbaum, The GIANT analysis system (graphical interactive aftershock network toolbox), Seismological Research Letters, 69(1), 40-45, 1998.

Rietbrock, A., C. Haberland, K. Bataille, T. Dahm, and O. Oncken, Studying the seismogenic coupling zone with a passive seismic array, EOS, 86(32), 2005.

Scholz, C. H., The Mechanics of Earthquakes and Faulting, second ed., Cambridge University Press, Cambridge, UK, 2002.

Song, T.-R. A., and M. Simons, Large trench-parallel gravity variations predict seismogenic behaviour in subduction zones, Science, 301, 630-633, 2003.

Tichelaar, B. W., and L. J. Ruff, Seismic coupling along the Chilean subduction zone, J. Geophys. Res., 96(B7), 1991.

Wessel, P., and W. Smith, New, improved version of the Generic Mapping Tools released, Eos Trans. AGU, 79, 579, 1998. 
Figure 1. Tectonic Setting of the South Chilean continental margin at the Arauco Peninsula (AP) and seismological stations (inverted triangles). Thick black line show continental faults (MVZF: Mocha-Villarica Fault Zone, LFZ: Lanalhue Fault, BBFZ: BioBio Fault Zone, LOFZ: Liquiñe-Ofqui Fault Zone) following Melnick and Echtler [2006]; MFZ: Mocha Fracture Zone, VFZ: Valdivia Fracture Zone. Young volcanos are depicted by triangles, earthquakes $(\leq M=5.5)$ since 1960 are shown by white circles. The epicenter of the $M=9.5$ earthquake of 1960 is shown by the black star, the approximate region of associated uplift and subsidence is shown by the dashed line [Plafker and Savage, 1970]. All earthquake locations following Engdahl et al. [1998] and Engdahl and Villaseñor [2002]. Areas above $700 \mathrm{~m}$ are shown in dark grey. Box indicates study region.

Figure 2. (Top) Minimum 1-D velocity model. Dashed lines indicate limits of starting models used, grey lines represent final models, thick black lines give final model with lowest overall rms. We only used events with $\mathrm{GAP} \leq 180^{\circ}$ and at least $10 \mathrm{P}$ and $5 \mathrm{~S}$ observations. (Bottom) P-wave station corrections corresponding to the final velocity model. The reference station is indicated by the star. For computational reasons the depths of the OBS/OBH were fixed to sea level, and the derived station delays also account for the corresponding effect [Husen et al., 1999]. 
Figure 3. Mislocations of 44 artifical explosions to check the accuracy of the earthquake positions. Shown by circles are differences between the true positions and the relocations by the inversion, bars are histograms. Only shots with more than 14 observations and only $\mathrm{P}$ observations were used. The distribution suggests that the horizontal location uncertainty is about $1 \mathrm{~km}$, the vertical uncertainty around $500 \mathrm{~m}$. Inset shows shot locations.

Figure 4. Local seismicity observed by the temporal network (top: map view, bottom: two WE-depth sections). High-quality earthquakes used in the inversion are depicted by circles. Filled circles indicate earthquakes shallower than $17 \mathrm{~km}\left(\mathrm{~W}\right.$ of $\left.73^{\circ} \mathrm{W}\right)$ and $30 \mathrm{~km}$ (E of $73^{\circ} \mathrm{W}$ ), respectively. Crosses depict relocated seismicity not used in the calculation of the minimum 1-D model. Black triangles indicate recent volcanoes. Faults (solid lines) after Melnick and Echtler [2006], dashed black line depicts inferred fault. Seismicity is unevenly distributed and can be associated to the thrust plane (A), to crustal faults with different orientation (B, C, D), and to the intermediate depth level (E). Fault plane solutions (lower hemisphere plot) are based on first motion polarities (leftmost beachball corresponds to $5.2 M_{L}$ event on February 4, 2005; date and magnitude given on top). Light grey lines indicate inferred top of subducting slab. For more information see text. 


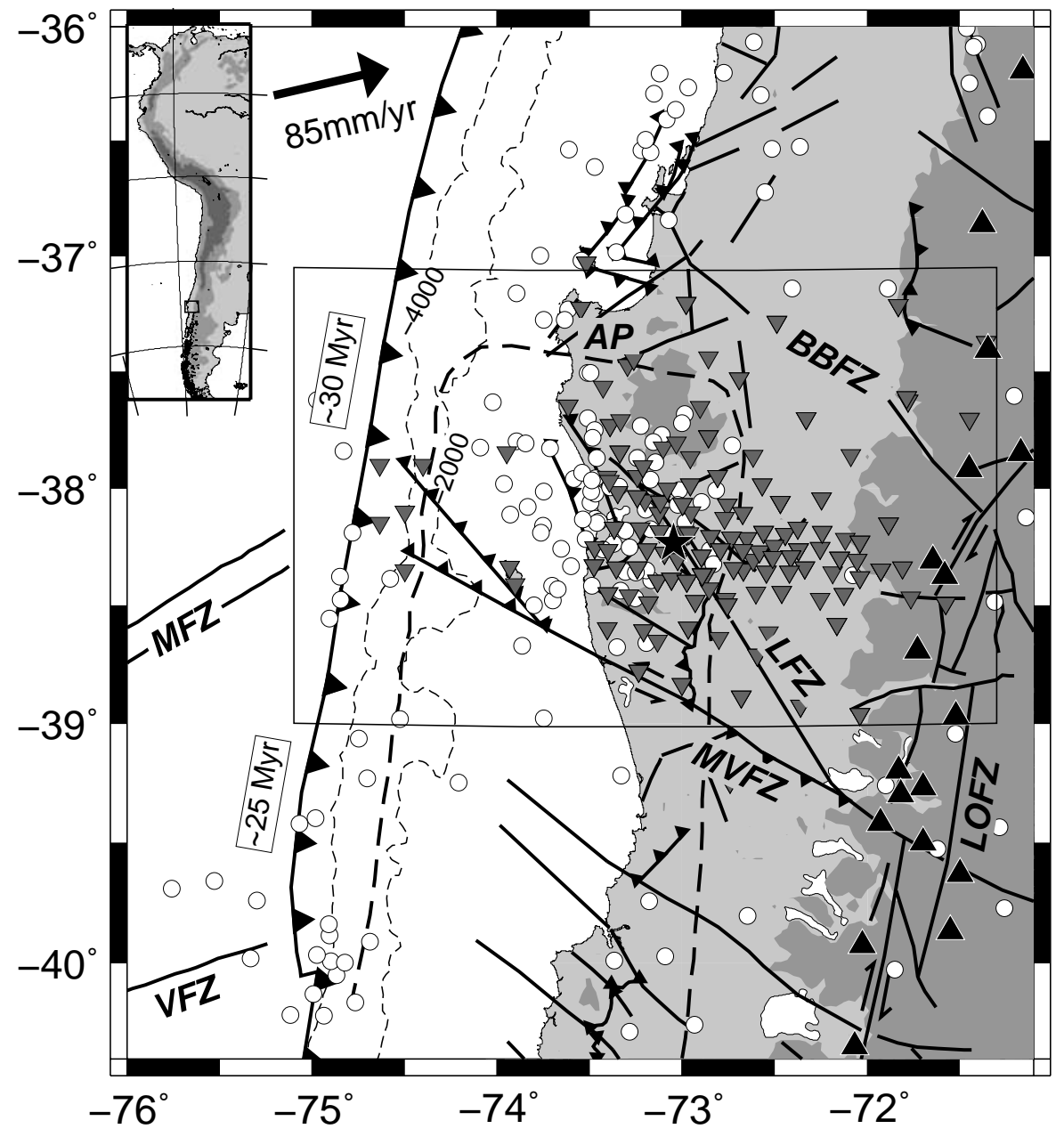

GM) 2006 Sep 6 13:06:06 Figure 1 


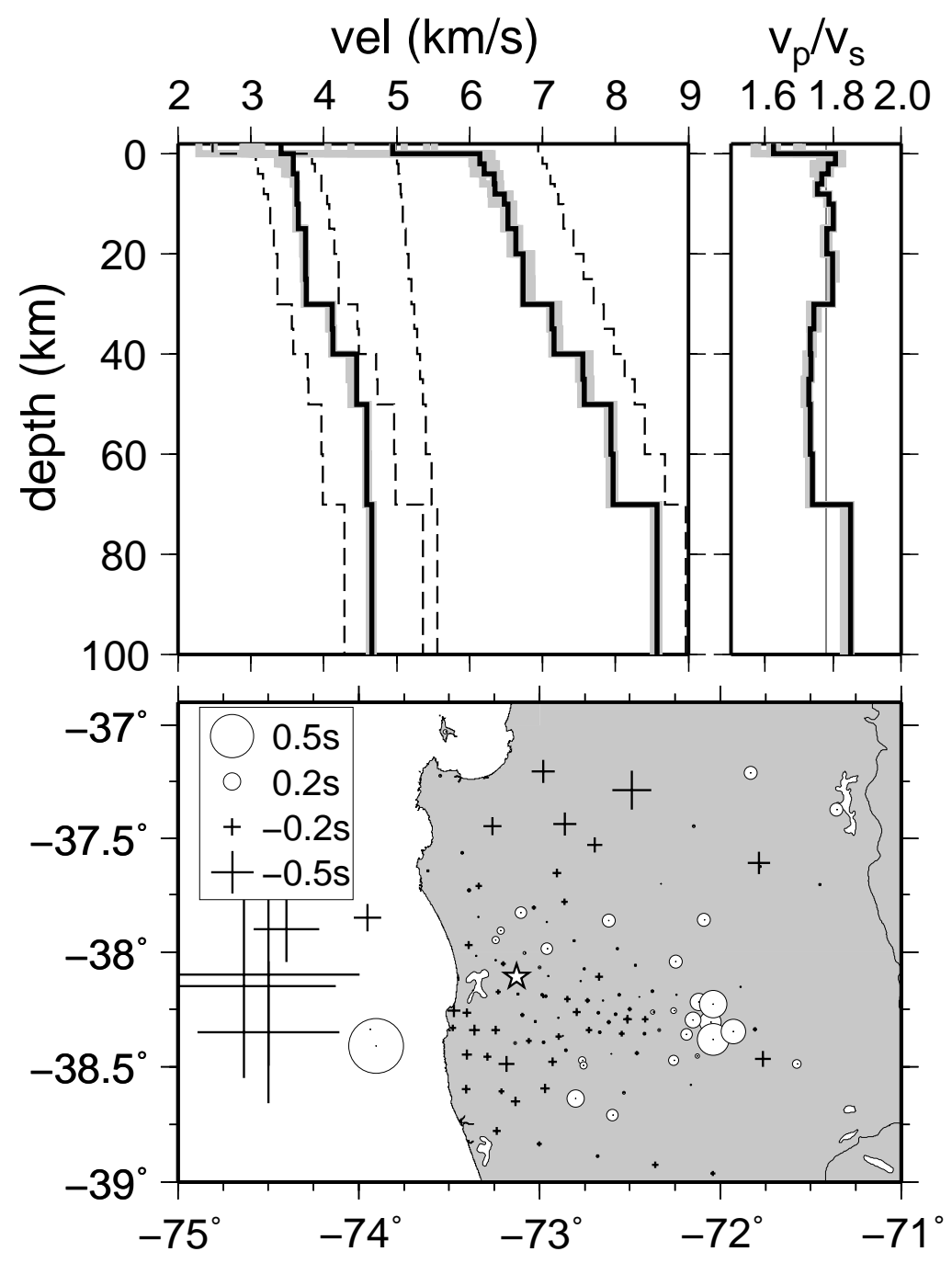

GMJ 2006 Oct 19 17:03:24 Figure 2 


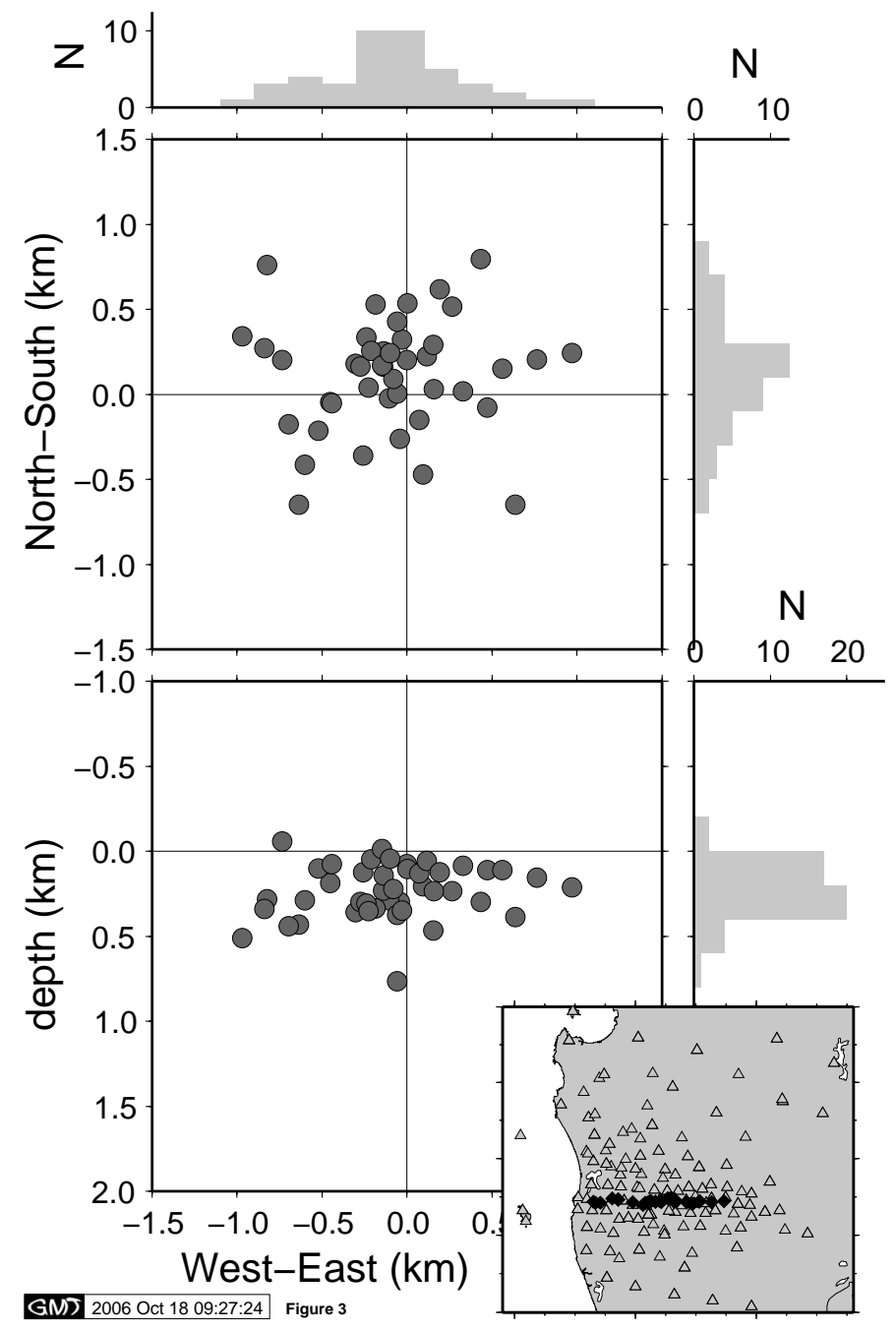




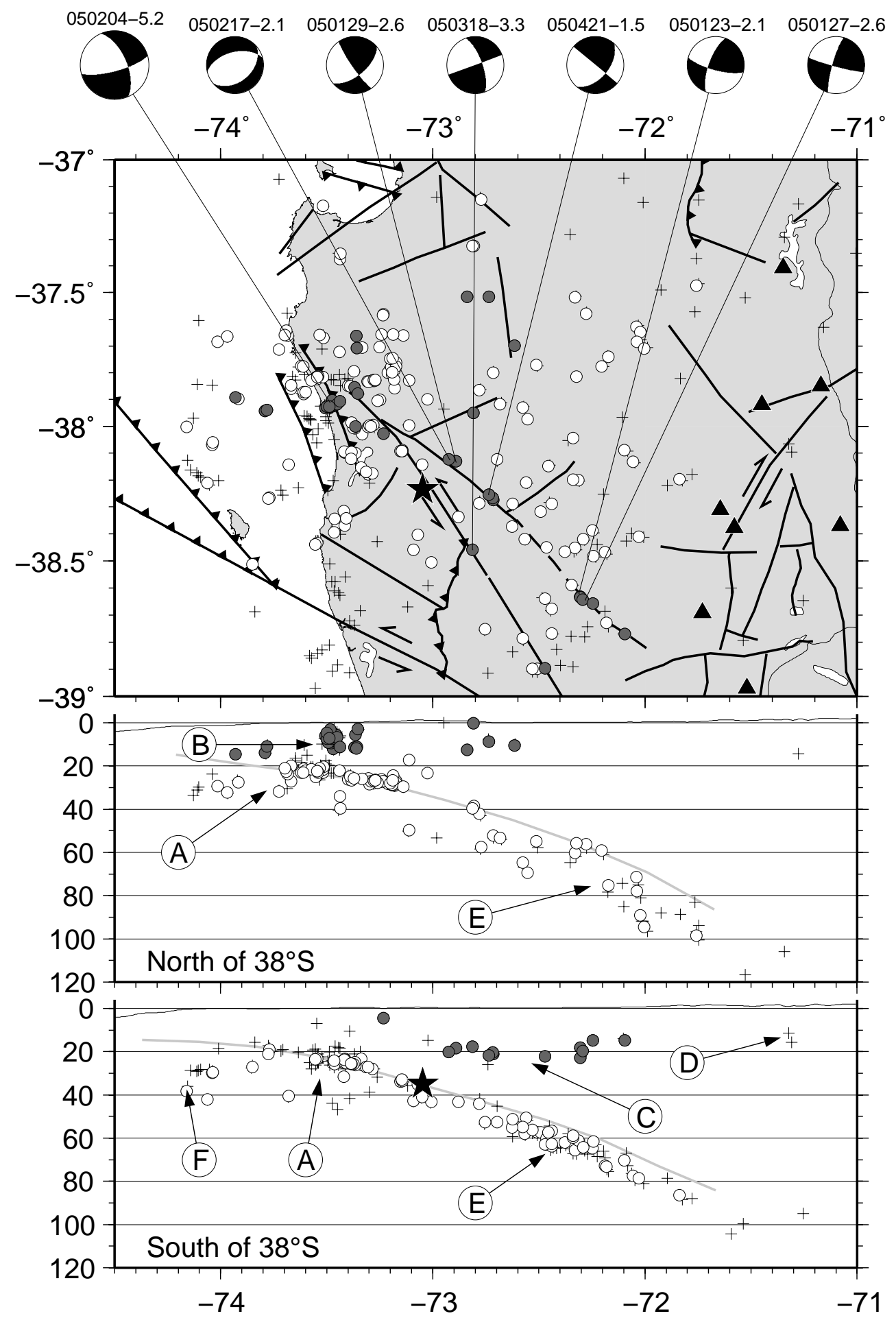

GND 2006 Oct 19 16:39:07 Figure 4 